ACTA VET. BRNO 2001, 70: 457-465

\title{
THE EFFECT OF DIAZINON ON HAEMATOLOGICAL INDICES OF COMMON CARP (Cyprinus carpio L.)
}

\author{
M. SVOBODA ${ }^{1}$, V. LUSKOVÁ ${ }^{2}$, J. DRASTICHOVÁ ${ }^{1}$, V. ŽLÁBEK ${ }^{3}$ \\ ${ }^{1}$ University of Veterinary and Pharmaceutical Sciences, Brno, Czech Republic \\ ${ }^{2}$ Institute of Vertebrate Biology, AS CR, Brno, Czech Republic \\ ${ }^{3}$ University of South Bohemia, Research Institute of Fish Culture and Hydrobiology, Vodňany, Czech Republic
}

Received April 4, 2001

Accepted October 31, 2001

\section{Abstract}

Svoboda M., V. Lusková, J. Drastichová, V. Žlábek: The Effect of Diazinon on Haematological Indices of Common Carp (Cyprinus carpio L). Acta Vet. Brno 2001, 70: 457-465.

The goal was to assess an effect of diazinon [0,0-diethyl 0-(2-isopropyl-6-methylpyrimidin-4yl) phosphorothioate] on common carp (Cyprinus carpio L.). The effect was assessed based on results of acute toxicity tests and on a comparison of results of haematological examination of a control and an experimental group exposed to Basudin $600 \mathrm{EW}$ pesticide preparation (active substance $600 \mathrm{~g} . \mathrm{l}^{-1}$ of diazinon). The acute toxicity test lasting $96 \mathrm{~h}$ was performed semistatically on common carp juveniles. Examination of erythrocyte and leukocyte profile was performed on 15 control and 25 experimental specimens of one-to-two-year-old common carp after $96 \mathrm{~h}$ of exposure to Basudin 600 EW in concentration of $32.5 \mathrm{mg} \cdot \mathrm{l}^{-1}$. The 96hLC50 value of Basudin $600 \mathrm{EW}$ for common carp juveniles was $26.7 \mathrm{mg} \cdot \mathrm{l}^{-1}$. The experimental group of one- to two-year-old common carp showed significantly lower values $(p<0.01)$ of erythrocyte count $(\mathrm{RBC})$, haemoglobin content $(\mathrm{Hb})$ and haematocrit (PCV) compared to the control group. Values of MCV, MCH and MCHC were comparable in both groups during the study. In contrary, there was a significant decrease in leukocyte count (Leuko) $(p<0.01)$, as well as in both the relative and absolute lymphocyte count $(p<0.01)$ and a significant increase in both the relative and absolute count of developmental forms of neutrophile granulocytes: myelocytes $(p<0.01)$ and metamyelocytes $(p<0.05)$ in the experimental group. Relative and absolute count of monocytes and both the band- and segmented neutrophile granulocytes was comparable in both groups during the study. The diazinon-based Basudin $600 \mathrm{EW}$ pesticide preparation was classified among harmful substances for fish. Changes in values of both the erythrocyte and leukocyte profile after exposure to diazinon-based preparation may be refered to disruption of haematopoiesis as well as to a decrease on non-specific immunity of the fish.

Organophosphorous pesticide, acute toxicity, erythrocyte profile, leukocyte profile

Organophosphorous pesticides have fully replaced the persistant chlorinated pesticides in the 1970's and on the beginning of 1980's. The main advantage of the organophosphorous pesticides was their low cummulative ability and short-term persistance in the environment. Although the organophosphorous pesticides have been replacing by pyrethroid-based pesticides within the last 10-15 years, there is still a very intensive utilization of organophosphates. Organophosphorous pesticides are also utilized in fish culture (mainly those based on dichlorvos and trichlorfon) in order to suppress some parasitary diseases such as monogeneoses and arthropodoses (Noga 1995; Schlotfeldt and Alderman 1995; Čítek et al. 1998; Navrátil et al. 2000). Nevertheless, the pesticide preparations are considered harmful for fish in most cases (Svobodová et al. 1998).

Diazinon is a common active substance of organophosphorous pesticides (Roberts and Huts on 1998). Scholz et al. (2000) reported that not all of its effects to fish organism are known, despite of its very intensive use. Although the aquatic environment is not the main target and the aquatic invertebrates are not the target organisms, presence of diazinon in water was reported and its negative effect to aquatic organisms is proven. The ELISA assay 
and a biological toxicity test on Ceriodaphnia dubia (Mansingh and Wilson 1995; Tsuda et al. 1996; Bailey et al. 2000; De-Vlaming et al. 2000) is used for monitoring of diazinon and of its metabolite diazoxon in water and in running water bottom sediments. Van-Der Geest et al. (1997) described an accidental pollution of Mense River (The Netherlands) with diazinon, as well as the negative consequences of this pollution, mainly the kill of aquatic invertebrates.

The mechanism of a toxic effect of diazinon is the same as of other organophosphorous substances. There is an inhibition of a whole series of enzymes and mainly of acetylcholinesterase (Goodman et al. 1979; Sastry and Sharma 1980; Ansari et al. 1987; Hamm et al. 1998).

There are differences in the acute toxicity of diazinon for various fish species. The 96hLC50 values range in tenths to several tens of $\mathrm{mg} \cdot \mathrm{l}^{-1}$ (Seikai 1982; Hidaka et al. 1984; Keizer et al. 1991; Oh et al. 1991; Keizer et al. 1993; Kikuchi et al. 1996; Giddings et al. 1996; Tsuda et al. 1997). In European eel (Anguilla anguilla) the 96hLC50 values range even in hundredths of $\mathrm{mg} \cdot \mathrm{l}^{-1}$ (S ancho et al. 1992ab, 1993). The different toxicity of diazinon may be demonstrated on the example of two fish species used for ecotoxicological assessment of chemical substances. The 96hLC50 value of diazinon for guppy (Poecilia reticulata) was found to be $0.8 \mathrm{mg} \cdot \mathrm{l}^{-1}$ but for zebrafish (Brachydanio rerio) it was found to be $8 \mathrm{mg} \cdot \mathrm{l}^{-1}$ (Keizer et al. 1991). Oh et al. (1991) present three factors causing the selective toxicity of diazinon for various fish species: different inhibition of acetylcholinesterase, different detoxification and absorption.

Increased attention is recently paid to the assessment of toxic effect of diazinon to reproduction and embryolarval development of fish. Moore et Waring (1996) and Wall (2000) reported significantly reduced levels of the reproductive steroids in zebrafish (Danio rerio) and Atlantic salmon (Salmo salar) after sublethal doses of diazinon. Hatchability was observed to be $30 \%$ and $50 \%$ in eggs obtained from the mother fish exposed chronically to $2.6 \mathrm{mg} \cdot \mathrm{l}^{-1}$ and $1.3 \mathrm{mg} \cdot \mathrm{l}^{-1}$ for 30 days respectively (Iqbal et Mufti 1992). A decreased hatchability of medaka (Oryzias latipes) exposed to diazinon was also reported (Hamm 2000). Embryolarval toxicity assays with diazinon were performed on various fish species: the Japanese stripped knifejaw, Oplegnathus fasciatus (Seikai 1982); Japanese flounder, Paralichthys olivacens (Menendez et Ishimatsu 1993); rainbow trout, Oncorhynchus mykiss (Kikuchi et al. 1996) and medaka, Oryzias latipes (Ha mm 2000). Decreased total length of the larval body was a highly sensitive indicator of the diazinon effect in the course of embryolarval development.

Histopathological alterations after the exposure to diazinon in various fish species are described by several authors. Hamm et al. (1998) reported an increased occurrence of retinal cells necrosis in medaka. Dutta et al. (1993) described the gill alterations in bluegill sunfish, Lepomis macrochirus (lifting of the epithelial layer, hyperplasia and necrosis, shortening of the lamellae and frequent epithelial rupture, lamellar fusion and mucous cells hypertrophy). The ultrastructural alterations in skeletal muscle of Tilapia nilotica after poisoning with diazinon were reported by $\mathrm{Sakr}$ et Garb (1992). Finding of increased amount of macrophages in kidney and spleen of bluegill sunfish, Lepomis macrochirus after exposure to diazinon were reported by Dutta et al. (1997). Sublethal concentrations of diazinon caused serious damage to gut wall in a freshwater teleost Channa punctatus (Anees 1976).

The greatest attention to the problems of bioaccumulation and excretion of diazinon in freshwater fish was paid in early 1990's (Seguchi et Asaka 1981; Tsuda et al. 1989, 1991, 1995ab, 1997; Sancho et al. 1992ab, 1993). Bioconcentration factor (BCF) of diazinon differs in various fish species. For example the BCF value in eel, Anguilla anguilla after $96 \mathrm{~h}$ exposure to $0.042 \mathrm{mg} \cdot \mathrm{l}^{-1}$ concentration was 1850 in liver and 775 in muscle 
(Sancho et al. 1992a). In contrary, the BCF value in common carp, Cyprinus carpio was 60 in liver and 21 in muscle (Gangolli 1999).

Data on toxicity of pesticide preparations and its effects to non-target organisms are the basic ones for determination of ecotoxicological riscs of pesticides for the ecosystem. Fish are considered among the non-target aquatic organisms as well. The present paper contributes to the assessment of toxicity and of the effect of an organophosphorous diazinon based pesticide.

\section{Materials and Methods}

The goal was to assess an effect of diazinon [0,0-diethyl 0-(2-isopropyl-6-methylpyrimidin-4yl) phosphorothioate] on fish. It was tested in the form of Basudin $600 \mathrm{EW}$ pesticide, the active substance of which is diazinon in amount of $600 \mathrm{~g} .1^{-1}$. The toxic effect was assessed based on results of acute toxicity tests and on results of haematological examination of common carp after exposure to this pesticide.

The acute toxicity test on common carp with Basudin 600 EW followed the OECD Direction No. 203 and Methodical Manual ISO 7346/2. Juveniles of common carp (Cyprinus carpio L.) with $9.0 \pm 2.32 \mathrm{~g}$ mean body weight and $67.2 \pm 6.76 \mathrm{~mm}$ mean body length were used for the test. Seven various concentrations and a control were used in the basic test. Ten fish specimens were used for every concentration and also in control. The test was performed semistatically for $96 \mathrm{~h}$. Bath was changed every $24 \mathrm{~h}$. Basic physical and chemical indices of diluting water used in the acute toxicity test were as follows: $\mathrm{pH} 7.82 ; \mathrm{ANC}_{45}$ (alkalinity) $1.05 \mathrm{mmol} \cdot \mathrm{l}^{-1} ; \mathrm{BNC}_{3}$ (acidity) $0.03 \mathrm{mmol} \cdot \cdot^{-1} ; \mathrm{COD}_{\mathrm{Mn}} 1.0 \mathrm{mg} \cdot \mathrm{l}^{-1} ; \mathrm{NH}_{4}{ }^{+}+\mathrm{NH}_{3} 0.1 \mathrm{mg} \cdot \mathrm{l}^{-1} ; \mathrm{NO}_{3}{ }^{-1} 1.56 \mathrm{mg} \cdot \mathrm{l}^{-1} ; \mathrm{NO}_{2}^{-} 0.015 \mathrm{mg} \cdot \mathrm{l}^{-1} ; \mathrm{PO}_{4}^{3-} 0.01 \mathrm{mg} \cdot \mathrm{l}^{-1} ;$ sum of $\mathrm{Ca}+\mathrm{Mg} 14 \mathrm{mg} \cdot \mathrm{l}^{-1}$. Water temperature in the test ranged from 19 to $21{ }^{\circ} \mathrm{C}$, oxygen saturation of water ranged between 70 and $100 \%$. The LC50 and LC5 values in the respective time intervals were determined by probit analysis.

Haematological examination of one-to-two-year-old common carp (Cyprinus carpio L.) was performed at the end of $96 \mathrm{~h}$ acute toxicity test with Basudin $600 \mathrm{EW}$ in concentration of $32.5 \mathrm{mg} \cdot \mathrm{l}^{-1}$. At the same time, the control group of common carp was also examined haematologically. The test was performed semistatically with bath exchange every $24 \mathrm{~h}$. Diluting water was of the same physical and chemical parameters as described above. Water temperature during the test ranged from 21.0 to $21.8^{\circ} \mathrm{C}$, oxygen saturation of water was above $60 \%$ (ranging from 90 to $110 \%$ ), pH ranged from 7.65 to 7.82 . The test was performed in 6 aquaria of 2001 volume. Each aquarium was stocked with 10 specimens of one- to two-year-old common carp (2 control aquaria, 4 aquaria with concentration of $32.5 \mathrm{mg} \cdot \mathrm{l}^{-1}$ Basudin $600 \mathrm{EW}$ ).

Examination of erythrocyte and leukocyte profile was carried out on 15 control (body weight $249 \pm 60.7 \mathrm{~g}$ ) and on 25 experimental specimens (body weight $272 \pm 49.7 \mathrm{~g}$ ) after $96 \mathrm{~h}$ exposure to concentration of $32.5 \mathrm{mg} \cdot \mathrm{l}^{-1}$ Basudin $600 \mathrm{EW}$.

Blood was sampled by cardiac punction and stabilized with $50 \mathrm{IU}$ sodium heparin per $1 \mathrm{ml}$ blood. We determined erythrocyte count (RBC), haematocrit (PCV), haemoglobin (Hb), mean corpuscular volume (MCV), mean corpuscular haemoglobin (MCH), mean corpuscular haemoglobin concentration (MCHC), leukocyte count (Leuko) and differential leukocyte count (S vobodová et al. 1991). Results were processed statistically by means of the analysis of variance (ANOVA).

\section{Results}

\section{Acute Toxicity}

The LC50 a LC5 values of Basudin $600 \mathrm{EW}$ for common carp juveniles in the respective time intervals are given in Fig. 1. The 96hLC50 is basic value in the acute toxicity test. For

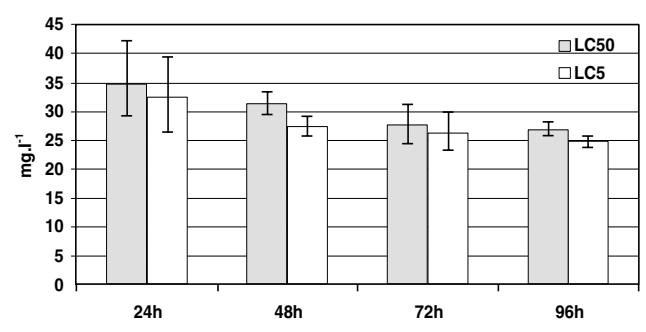

Fig. 1. Acute toxicity test of Basudin $600 \mathrm{EW}$ pesticide in common carp (range means $95 \%$ confidence interval) common carp juveniles the 96hLC50 value was $26.7 \mathrm{mg} \cdot \mathrm{l}^{-1}$ of Basudin $600 \mathrm{EW}$ preparation which is $16.0 \mathrm{mg} \cdot \mathrm{l}^{-1}$ of diazinon.

A neural paralytic syndrom was typical for fish poisoned with diazinon. Strong restlessness started when fish came into contact with the poisoning bath. Fish excitation was reflected by an increased reaction to exogenous stimuli and by cramp movements of fins and mouth. Loss of movement coordination began, as well 
Table 1

Derived haematological parameters in common carp affected by acute exposure to Basudin $600 \mathrm{EW}$

\begin{tabular}{|c|c|c|c|c|c|r|c|}
\hline Indices & Units & Groups & N & Means & SD & Variance & Probability \\
\hline & & control & 13 & 252.07 & 28.56 & 815.67 & \\
$\mathrm{MCV}$ & $\mathrm{fl}$ & experiment & 24 & 249.50 & 55.22 & 3049.24 & 0.88 \\
\hline & & control & 13 & 60.69 & 7.00 & 49.00 & \\
$\mathrm{MCH}$ & $\mathrm{pg}$ & experiment & 24 & 60.85 & 8.36 & 69.89 & 0.95 \\
\hline & & control & 15 & 0.24 & 0.02 & 0.00 & \\
$\mathrm{MCHC}$ & $1 \cdot 1^{-1}$ & experiment & 25 & 0.25 & 0.04 & 0.01 & 0.37 \\
\hline
\end{tabular}

as loss of orientation in water. The fish turned on the flank and swam in half-circles. Reaction to excitation was manifested by sudden movements and fin tremor. Body surface darkening was noticeable in this phase of poisoning, mainly on the dorsal part. Weakening of jerks or areflexia, paralysis, arrhythmia and block of respiration movements began in the terminal phase of poisoning. The fish fell into agony and died in a short time.

Pathological and anatomical signs found in fish poisoned with diazinon were not specific. Body surface was opaque with slightly increased amount of mucus and with expressive pigmentation mainly on the dorsal part. No changes on the eye. Gills had straight edges, normal colour, slightly increased amount of mucus. In the body cavity there was an evident injection of internal organ vessels, mainly hyperaemia of hepatopancreas.

\section{Haematological Profile}

Results of erythrocyte profile of both the control and experimental common carp under study are given in Fig. 2 and in Table 1. Compared to the control specimens, fish after an acute exposure to diazinon had lower erythrocyte count $(p<0.01)$, haemoglobin content $(p<0.01)$ and lower haematocrit value $(p<0.01)$. Values recorded for MCV, MCH and MCHC were comparable in both groups under study.

Table 2

Leukocyte differential count $\left(\mathrm{G} \cdot \mathrm{l}^{-1}\right)$ in commn carp affected by acute exposure to Basudin $600 \mathrm{EW}$

\begin{tabular}{|c|c|c|c|c|c|c|}
\hline Indices & Groups & $\mathrm{N}$ & Means & SD & Variance & Probability \\
\hline \multirow{3}{*}{ Lymphocytes } & control & 9 & 45.33 & 8.53 & 72.76 & \\
& experiment & 20 & 19.36 & 5.33 & 28.41 & $0.00^{* *}$ \\
\hline \multirow{3}{*}{ Monocytes } & control & 9 & 0.33 & 0.27 & 0.07 & \\
\hline \multirow{3}{*}{ Myelocytes } & experiment & 20 & 0.23 & 0.25 & 0.06 & 0.32 \\
\hline \multirow{3}{*}{ Metamyelocytes } & control & 9 & 0.40 & 0.28 & 0.08 & \\
\hline \multirow{3}{*}{ Band neutrophils } & experiment & 20 & 5.55 & 3.85 & 14.82 & $0.00 * *$ \\
\hline \multirow{2}{*}{ Segmend neutrophils } & control & 9 & 0.23 & 0.35 & 0.12 & \\
& experiment & 20 & 1.44 & 1.39 & 1.93 & $0.02 *$ \\
\hline
\end{tabular}

Marked effects are significant at $p<0.05$ and $p<0.01$. 


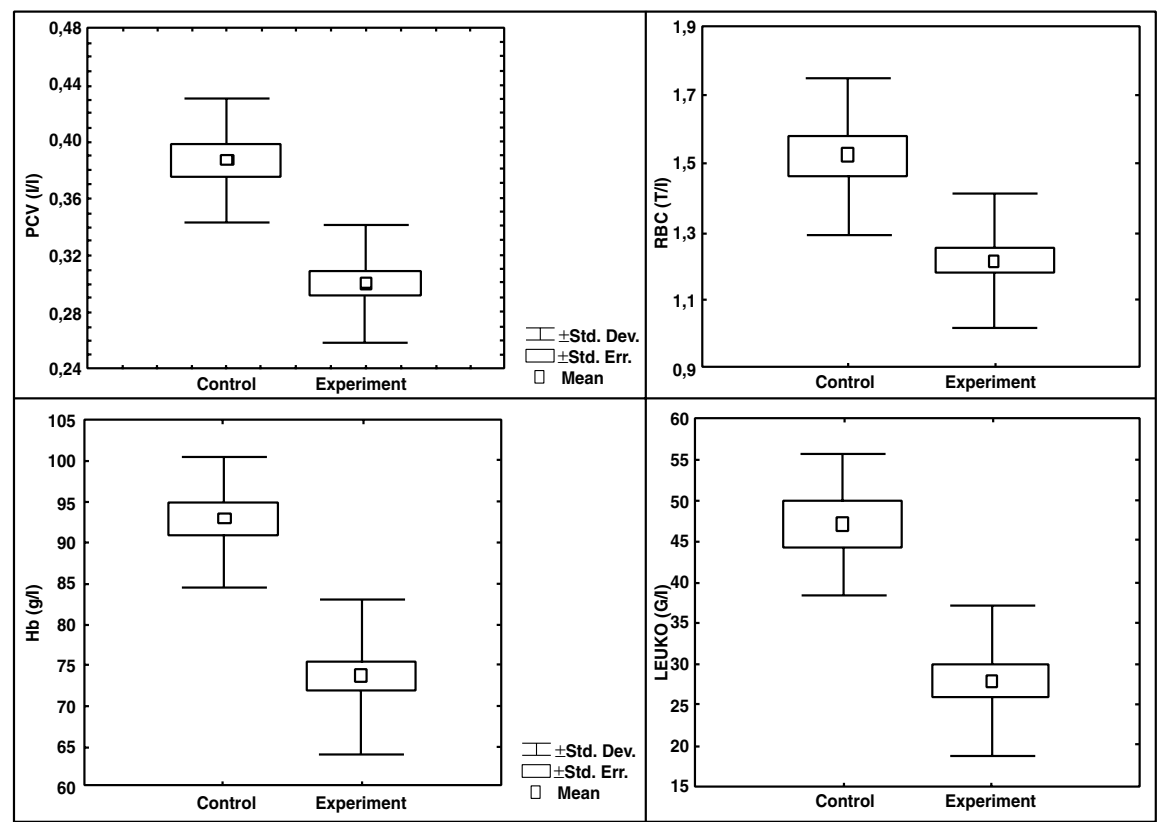

Fig. 2. Haematological indices significantly differentiated in control and experimental groups of common carp affected by acute exposure to Basudin $600 \mathrm{EW}$

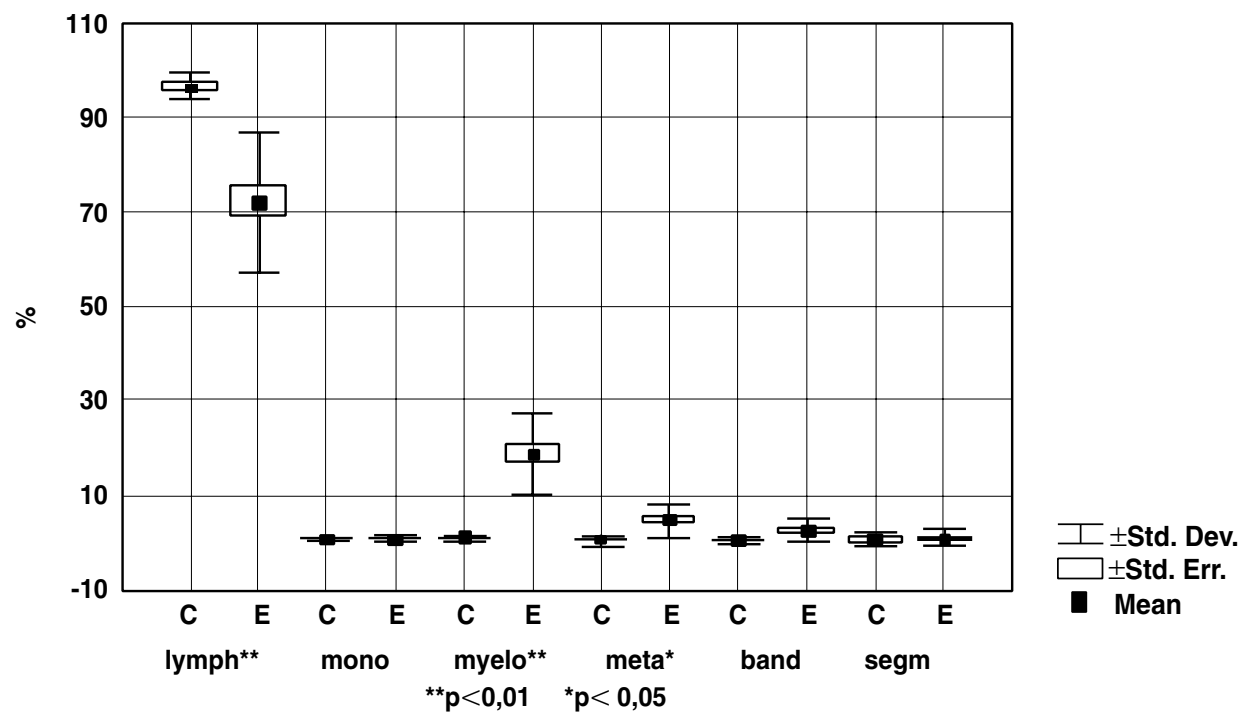

Fig. 3. Leukocyte differential count (\%) in control (C) and experimental (E) group of common carp affected by acute exposure to Basudin 600EW

Results of leukocyte profile of both groups under study are given in Figs. 2, 3 and in Table 2. It was evident that the acute exposure to diazinon resulted in lower leukocyte count $(p<0.01)$, as well as both the relative and absolute lymphocyte count $(p<0.01)$. In contrary, 
there was an increase in both the relative and absolute count of developmental forms of neutrophile granulocytes [myelocytes $(p<0.01)$, metamyelocytes $(p<0.05)$ ]. Differences in relative and absolute count of monocytes and/or band and segmented neutrophile granulocytes in neither of the groups under study were significant.

\section{Discussion}

In the course of $96 \mathrm{~h}$ toxicity test of diazinon-based organophosphorous preparation Basudin $600 \mathrm{EW}$ on common carp juveniles, there was no kill of fish in the control aquarium. Oxygen saturation of water did not drop below $60 \%$ in any concentration tested, nor in the control group. Presence of the substance tested (above $80 \%$ of the nominal concentration) was provided by means of daily exchange of the testing bath. Fulfilling these conditions, the test may be considered valid. Based upon the registered $96 \mathrm{hLC50}$ value $\left(26.7 \mathrm{mg} \cdot \mathrm{l}^{-1}\right)$, Basudin $600 \mathrm{EW}$ can be classified into the group of substances harmful for fish (risk sentence R52). This sentence reports the $96 \mathrm{hLC} 50$ values as $10-100 \mathrm{mg} \cdot \mathrm{l}^{-1}$. The $96 \mathrm{hLC} 50$ value $26.7 \mathrm{mg} \cdot \mathrm{l}^{-1}$ Basudin $600 \mathrm{EW}$ refers to $16.0 \mathrm{mg} \cdot \mathrm{l}^{-1}$ diazinon. This value was equal by order with the $96 \mathrm{hLC} 50$ value for Carassius auratus, where a $9.0 \mathrm{mg} \cdot \mathrm{l}^{-1}$ diazinon concentration was reported by Eis sler (1986). Similarly, it was equal by order also with 8.0 $\mathrm{mg} \cdot \mathrm{l}^{-1}$ diazinon that was the $96 \mathrm{hLC} 50$ value for Brachydanio rerio (Keizer et al. 1991). In contrary, the $96 \mathrm{hLC} 50\left(0.8 \mathrm{mg} \cdot \mathrm{l}^{-1}\right.$ diazinon) for cyprinodontid, Poecilia reticulata is by more than one order lower compared to that for common carp (Keizer et al. 1991). Specific sensitivity of fish to diazinon may be associated with different ability of absorption, acetylcholinesterase inhibition and detoxification, as reported by $\mathrm{Oh}$ et al. (1991).

The main haematological response of common carp to the acute exposure to diazinonbased organophosphorous pesticide in $32.5 \mathrm{mg} \cdot \mathrm{l}^{-1}$ concentration was a significant decrease $(p<0.01)$ of erythrocyte count, haematocrit value and haemoglobin content compared to the control group. Decreased erythrocyte count and haemoglobin content in freshwater fish Channa punctatus after acute exposure to diazinon was also reported by Anees (1978). Other effective substances of organophosphorous pesticides also induce changes which give evidence for decreased haematopoiesis followed by anemia induction in fish. It regards e.g. changes in erythrocyte profile induced by acute effect of dichlorvos in Clarias batrachus (Benarji and Rajendranath 1990), trichlorphon in Piaractus mesopotamicus (Tavares et al. 1999), malathion in Cyprinion wabsoni (Khattak and Hafee $\mathrm{z}$ 1996), formothion in Heteropneustes fossilis (Sing h and Srivastava 1994) and of Ekolux organophosphorous preparation in Oreochromis mossambicus (Sampath et al. 1993).

Another type of haematological response to the effect of organophosphorous compounds was a significant increment of mean corpuscular volume (MCV) associated with increment of haematocrit value and drop of MCHC. This response was registered in common carp after acute effect of phenitrothion, imidan and dichlorvos (S vobodová 1971, 1975). In contrary, values of $\mathrm{MCV}, \mathrm{MCH}$ and $\mathrm{MCHC}$ registered after $96 \mathrm{~h}$ exposure to diazinon-based pesticide in $32.5 \mathrm{mg} \cdot \mathrm{l}^{-1}$ concentration to common carp were comparable with the control group.

Significant decrease of leukocyte count and significant relative and absolute lymphopenia and granulocytosis characterize the leukocyte profile of common carp after the acute exposure to diazinon-based pesticide. Lymphopenia as a consequence of methylparathionbased pesticide was reported by $\mathrm{Nath}$ and B an erjee (1996) in Heteropneustes fossilis and also by Siwicki et al. (1990) in common carp after an acute effect of trichlorfon. Ghosh and Banerjee (1993) report lymphopenia and both neutrophile and eosinophile granulocytosis in Heteropneustes fossilis after an effect of dimethoate in 96hLC50 concentration. A decreased non-specific immunity in fish can be expected after acute exposure to organophosphorous pesticides due to decreased leukocyte count, lymphopenia and granulocytosis. Numerous authors report lymphopenia and granulocytosis after 
exposure to many pollutants (Wlasow 1985; Murad and Houston 1988; Schwaiger et al. 1993; Thakur and Sahai 1993, Alkahem 1994; Svobodová et al. 1996). These changes in differential leukocyte count also give evidence for decreased level of nonspecific immunity in fish after acute exposure to toxic substances.

\section{Vliv diazinonu na hematologické ukazatele kapra (Cyprinus carpio l.)}

Cílem práce bylo zhodnotit účinek diazinonu [0,0-diethyl 0-(2-isopropyl-6methylpyrimidin-4yl) phosphorothioate] na kapra obecného (Cyprinus carpio L.). Učinek byl posuzován na základě výsledků testu akutní toxicity a na základě porovnání výsledků hematologického vyšetření kontrolní a pokusné skupiny vystavené působení pesticidního přípravku Basudin $600 \mathrm{EW}$ (účinná látka $600 \mathrm{~g} \cdot \mathrm{l}^{-1}$ diazinonu). Test akutní toxicity byl proveden semistatickým zpo̊sobem po dobu 96 hod. na plůdku kapra. Vyšetření červeného a bílého krevního obrazu bylo provedeno u 15 kusů kontrolních $\mathrm{K}_{1-2}$ a u 25 kusů $\mathrm{K}_{1-2}$ po 96 hodinovém působení Basudinu $600 \mathrm{EW} \mathrm{v} \mathrm{koncentraci} 32,5 \mathrm{mg} \cdot \mathrm{I}^{-1}$. Hodnota $96 \mathrm{hLC} 50$ Basudinu $600 \mathrm{EW}$ pro plůdek kapra byla $26,7 \mathrm{mg} \cdot \mathrm{l}^{-1}$. U pokusné skupiny kaprů $\mathrm{K}_{1-2}$ byly zjištěny signifikantně nižší hodnoty $(p<0,01)$ počtu erytrocytů $(\mathrm{RBC})$, obsahu hemoglobinu (Hb) a hematokritu (PCV) ve srovnání s kontrolní skupinou. Hodnoty MCV, MCH a MCHC byly u pokusné a kontrolní skupiny srovnatelné. Naproti tomu bylo zjištěno signifikantní snížení počtu leukocytů (Leuko) $(p<0,01)$, relativního i absolutního počtu lymfocytů $(p<0.01)$ a signifikantní zvýšení relativního i absolutního počtu vývojových forem neutrofilních granulocytů [myelocyty $(p<0,01)$, metamyelocyty $(p<0,05)$ ] u pokusné skupiny ve srovnání s kontrolou. Relativní i absolutní počet monocytů a neutrofilních granulocytů s tyčkovitým a segmentovaným jádrem byl u obou porovnávaných skupin srovnatelný. Pesticidní př́ipravek na bázi diazinonu Basudin $600 \mathrm{EW}$ byl zařazen mezi látky škodlivé pro ryby. Na základě změn v hodnotách červeného a bílého krevního obrazu po působení př́ípravku na bázi diazinonu lze usuzovat na poruchu krvetvorby a na snížení nespecifické odolnosti ryb.

\section{Acknowledgements}

This research was supported by the Ministry of Education, Youth and Physical Training of the Czech Republic (MŠMT Project No. 162700004).

\section{References:}

ALKAHEM, H. F. 1994: The toxicity of nickel and the effects of sublethal levels on haematological parameters and behaviour of the fish, Orechromis niloticus. J. Univ. Kuwait. Sci. 21: 243-252

ANEES, M. A. 1976: Intestinal pathology in freshwater teleost, Channa punctatus (Bloch) exposed to sublethal and chronic levels of three organophosphorus insecticides. Acta Physiol. Lat. Am. 26: 63-67

ANEES, M. A. 1978: Haematological abnormalities in a freshwater teleost, Channa punctatus (Bloch), exposed to sublethal and chronic levels of three organophosphorus insecticides. Int. J. Ecol. Environ. Sci. 4: 53-60

ANSARI, B. A., ASLAM, M., KUMAR, K. 1987: Diazinon toxicity: Activities of acetylcholinesterase and phosphatases in the nervous tissue of zebra fish, Brachydanio rerio (Cyprinidae). Acta Hydrochim. Hydrobiol. 15: 301-306

BAILEY, H.C., DEANOVIC, L., REYES, E., KIMBALL, T., LARSON, K., CORTRIGHT, K., CONNOR, V., HINTON, D. E. 2000: Diazinon and chlorpyrifos in urban waterways in northern California, USA. Environ. Toxicol. Chem. 19: 82-87

BENARJI, G., RAJENDRANATH, T. 1990: Haematological changes induced by an organophosphorus insecticide in a freshwater fish Clarias batrachus (Linnaeus). Trop. Freshwat. Biol. 2: 197-202

ČÍTEK, J., SVOBODOVÁ, Z., TESARČÍK, J. 1998: Nemoci sladkovodních a akvarijních ryb. Informatorium, Praha, $218 \mathrm{p}$

DE-VLAMING, V., CONNOR, V., DIGIORGIO, C., BAILEY, H. C., DEANOVIC, L. A., HINTON, D. E. 2000: Application of whole effluent toxicity test procedures to ambient water quality assessment. Environ. Toxicol. Chem. 19: 42-62

DUTTA, H.M., RICHMONDS, C. R., ZENO, T. 1993: Effects of diazinon on the gills of bluegill sunfish, Lepomis macrochirus. J. Environ. Pathol. Toxicol. Oncol. 12: 219-227

DUTTA, H. M., QADRI, N., OJHA, J., SINGH, N. K., ADHIKARI, S., MUNSHI, J. S. D., ROY, P. K. 1997: Effect 
of diazinon on macrophages of bluegill sunfish (Lepomis macrochirus) a cytochemical evaluation. Bull. Environ. Contam. Toxicol. 58: 135-141

EISLER, R. 1986: Diazinon hazards to fish, wildlife, and invertebrates: A synoptic review. U. S. Fish Wildl. Serv., Biol. Rep. 85: 37 p.

GANGOLLI, S. 1999: The dictionary of substances and their effects. The Royal Society of Chemistry, Cambridge, 3: $142-146$

GHOSH, K., BANERJEE, V. 1993: Alteration in blood parameters in the fish Heteropneustes fossilis exposed to dimethoate. Environ. Ecol. 11: 979-981

GIDDINGS, J. M., BIEVER, R. C., ANNUNZIATO, M. F., HOSMER, A. J. 1996: Effects of diazinon on large outdoor pond microcosme. Environ. Toxicol. Chem. 15: 618-629

GOODMAN, L. R., HANSEN, D. J., COPPAGE, D. L., MOORE, J. C., MATTHEWS, E. 1979: Diazinon: chronic toxicity and brain acetylcholinesterase inhibition in the sheepshead minnow, Cyprinodon variegatus. Trans. Am. Fish. Soc. 108:479-488

HAMM. J. T. 2000: The role of development and duration of exposure to the embryotoxicity of diazinon. Aquat. Toxicol. 48: 403-418

HAMM, J. T., WILSON, B. W., HINTON, D. E. 1998: Organophosphate-induced acetylcholinesterase inhibition and embryonic retinal cell necrosis in vivo in the teleost (Oryzias latipes). Neurotoxicology 19: 853-870

HIDAKA, H., HATTANDA, M., TATSUKAWA, R. 1984: Avoidance of pesticides with medakas (Oryzias latipes). J. Agric. Chem. Soc. Japan. 58: 145-151

IQBAL, J., MUFTI, S. A. 1992: Effect of diazinon on egg hatchability in a freshwater teleost, Colisa fasciata. Proc. Pak. Congress Zool. 11: 231-238

KEIZER, J., Dę AGOSTINO, G., VITTOZZI, L. 1991: The importance of biotransformation in the toxicity of xenobiotics to fish. 1. Toxicity and bioaccumulation of diazinon in guppy (Poecilia reticulata) and zebra fish (Brachydanio rerio). Aquat. Toxicol. 21: 239-254

KEIZER, J., Dę AGOSTINO, G., NAGEL, R., GRAMENZI, F., VITTOZZI, L. 1993: Comparative diazinon toxicity in guppy and zebra fish: Different role of oxidative metabolism. Environ. Toxicol. Chem. 12: 1243-1250

KHATTAK, I. U. D., HAFEEZ, M. A. 1996: Effect of malathion on blood parameters of the fish, Cyprinion watsoni. Pak. J. Zool. 28: 45-49

KIKUCHI, M., MIYAGAKI, T., WAKABAYASHI, M. 1996: Evaluation of pesticides used in golf links by acute toxicity test on rainbow trout. Nippon Suisan Gakkaishi 62: 414-419

MANSINGH, A., WILSON, A. 1995: Insecticide contamination of Jamaican environment. 3. Baseline studies on the status of insectidical pollution of Kingston Harbour. Mar. Pollut. Bull. 30: 640-645

MENENDEZ, M. S., ISHIMATSU, A. 1993: Pesticide toxicity in the larvae of Japanese flounder, Paralichthys olivaceus. Bull. Fac. Fish. Nagasaki Univ. Chodai Suikenpo, 74/75: 31-36

MOORE, A., WARING, C. P. 1996: Sublethal effects of the pesticide diazinon on olfactory function in mature male Atlantic salmon parr. J. Fish Biol. 48: 758-775

MURAD, A., HOUSTON, A. H. 1988: Leucocytes and leucopoietic capacity in goldfish, Carassius auratus, exposed to sublethal levels of cadmium. Aquat. Toxicol. 13: 141-154

NATH, R., BANERJEE, V. 1996: Effect of pesticides methylparathion and cypermethrin on the air-breathing fish Heteropneustes fossilis. Environ. Ecol. 14: 163-165

NAVRÁTIL, S., SVOBODOVÁ, Z., LUCKY, Z. 2000: Choroby ryb. Ediční středisko VFU, Brno, 155 p.

NOGA, J. E. 1995: Fish Disease. Diagnosis and Treatment. Mosby, St. Louis, 367 p.

OH, H. S., LEE, S. K., KIM Y. H., ROH, J. K. 1991: Mechanism of selective toxicity of diazinon to killifish (Oryzias latipes) and loach (Misgurnus anguillicaudatus). Aquatic Toxicology and Risk Assessment. 14: 343-353

ROBERTS, T. R., HUTSON, D. H. 1998: Metabolic Pathways of Agrochemicals. Part 2: Insecticides and Fungicides. The Royal Soc. Chem. Cambridge, 1475 p.

SAKR, S. A., GABR, S. A. 1992: Ultrastructural changes induced by diazinon and neopybuthrin in skeletal muscles of Tilapia nilotica. Bull. Environ. Contam. Toxicol. 48: 467-473

SAMPATH, K., VELAMMAL, S., KENNEDY, I.J., JAMES, R. 1993: Haematological changes and their recovery in Oreochromis mossambicus as a function of exposure period and sublethal levels of Ekalux. Acta Hydrobiol. 35: $73-83$

SANCHO, E., FERRANDO, M.D., ANDREAU, E., GAMON, M. 1992a: Acute toxicity, uptake and clearance of diazinon by the European eel, Anguilla anguilla L. J. Environ. Sci. Health, Part B: Pestic., Food Contam., Agric. Wastes B27: 209-221

SANCHO, E., FERRANDO, M.D., GAMON, M., ANDREU-MOLINER, E. 1992b: Organophosphorus diazinon induced toxicity in the fish Anguilla anguilla L. Comp. Biochem. Physiol. 103C: 351-356

SANCHO, E., FERRANDO, M. D., ANDREAU, E., GAMON, M. 1993: Bioconcentration and excretion of diazinon by eel. Bull. Environ. Contam. Toxicol. 50: 578-585

SASTRY, K. V., SHARMA, K. 1980: Diazinon effect on the activities of brain enzymes from Opiocephalus punctatus (Channa). Bull. Environ. Contam. Toxicol. 24: 326-332

SCHLOTFELDT, H. J.,ALDERMAN, D. J. 1995: What should I do? A practical guide for the freshwater fish farmer. Warwick Press, Weymouth, $60 \mathrm{p}$. 
SCHOLZ, N. L., TRUELOVE, N. K., FRENCH, B. L., BEREJIKIAN, B. A., QUINN, T. P., CASILLAS, E. COLLIER, T. K. 2000: Diazinon disrupts antipredator and homing behaviors in chinook salmon (Oncorhynchus tshawytscha). Can. J. Fish Aquat. Sci. 57: 1911-1918

SCHWAIGER, J., HOFFMANN, R., NEGELE, R. D. 1993: Haematology in evaluation of experimental intoxication of fish. In : Ichthyohaematology, $3^{\text {rd }}$ Conference, Research Institute of Fish Culture and Hydrobiology Vodňany, Czech Republic, Litomyšl, pp. 155-160

SEIKAI, T. 1982: Acute toxicity of organophosphorous insecticides on the developmental stages of eggs, larvae and juveniles of Japanese striped knifejaw Oplegnathus fasciatus. Bull. Jap. Soc. Sci. Fish. 48: 599-603

SEGUCHI, K., ASAKA, S. 1981: Intake and excretion of diazinon in freshwater fishes. Bull. Environ. Contam. Toxicol. 27: 244-249

SINGH, N. N., SRIVASTAVA, A. K. 1994: Formothion induced haematological changes in the freshwater Indian catfish Heteropneustes fossilis. J. Ecotox. Environ. Monit. 4: 137-140

SIWICKI, A. K., COSSARINI-DUNIER, M., STUDNICKA, M., DEMAEL, A. 1990: In vivo effect of the organophosphorus insecticide trichlorphon on immune response of carp (Cyprinus carpio). II. Effect of high doses of trichlorphon on nonspecific immune response. Ecotox. Environ. Saf. 19: 99-105

SVOBODOVÁ, Z. 1971: Some haematological and metabolic changes in fish occurring after pesticide intoxication. Bull. VÚR Vodňany 7: 29-36

SVOBODOVÁ, Z. 1975: Changes in the blood picture of the carp intoxicated with organophosphate pesticides. Acta Vet. Brno 44: 49-52

SVOBODOVÁ,Z., MÁCHOVÁ, J., KOLÁŘOVÁ, J., VYKUSOVÁ, B., PIAČKA, V. 1996: The effect of selected negative factors on haematological parameters of common carp, Cyprinus carpio L. and tench, Tinca tinca L. Proc. Sci. Papers to the $75^{\text {th }}$ Anniversary of Foundation of the RIFCH Vodňany, pp. 95-105

SVOBODOVÁ, Z., PRAVDA, D., PALÁČKOVÁ, J. 1991: Unified methods of haemathological examination of fish. Research Institute of Fish Culture and Hydrobiology, Vodňany, $31 \mathrm{p}$

SVOBODOVÁ, Z., VYKUSOVÁ, B., GROCH, L. 1998: Pesticides and fish poisoning. Agrochemicals and Animal Poisoning: Towards Toxicovigilance, IUTOX-Satellite Meeting, Lyon, 7 p.

TAVARES, D. M., MARTINS, M. L., NASCIMENTO, K.S. 1999: Evaluation of the haematological parameters in Piaractus mesopotamicus Holmberg (Osteichthyes, Characidae) with Argulus sp. (Crustacea, Branchiura) infestation and treatment with organophosphate. Rev. Bras. Zool. 16: 553-555

THAKUR, N., SAHAI, S. 1993: Differential leucocyte counts of some fishes during malathion intoxication. Environ. Ecol. 11: 875-878

TSUDA, T., AOKI, S., KOJIMA, M., HARADA, H. 1989: Bioconcentration and excretion of diazinon, IBP, malathion and fenitrothion by willow shiner. Toxicol. Environ. Chem. 24: 185-190

TSUDA, T., AOKI, S., KOJIMA, M., HARADA, H. 1991: Pesticides in water and fish from rivers flowing into Lake Biwa. Toxicol. Environ. Chem. 34: 39-55

TSUDA, T., AOKI, S., INOUE, T., KOJIMA, M. 1995a: Accumulation of diazinon, fenthion and fenitrothion by killifish from mixtures of the three pesticides. Toxicol. Environ. Chem. 47: 251-255

TSUDA, T., AOKI, S., INOUE, T., KOJIMA, M. 1995b: Accumulation and excretion of diazinon, fenthion and fenitrothion by killifish: Comparison of individual and mixed pesticides. Water Res. 29: 455-458

TSUDA, T., INOUE, T., KOJIMA, M., AOKI, S. 1996: Pesticides in water and fish from rivers flowing into lake Biwa. Bull. Environ. Contam. Toxicol. 57: 442-449

TSUDA, T., KOJIMA, M., HARADA, H., NAKAJIMA, A., AOKI, S. 1997: Acute toxicity, accumulation and excretion of organophosphorus insecticides and their oxidation products in killifish. Chemosphere 35: 939-949

VAN DER GEEST, H. G., STUIJFZAND, S. C., KRAAK, M. H. S., ADMIRAAL, W. 1997: Impact of diazinon calamity in 1996 on the aquatic macroinvertebrates in the River Mesue, The Netherlands. Neth. J. Aquat. Ecol. 30: $327-330$

WALL, S. B. 2000: Sublethal effects of cadmium and diazinon on reproduction and larval behaviour in zebrafish. Diss. Abst. Inter. Part B. Sci. and Eng. 60: 3829

WLASOW, T., 1985. The leukocyte system in rainbow trout, Salmo gairdneri Rich., affected by prolonged subacute phenol intoxication. Acta Ichthyol. Piscator. 15: 83-94

Fish acute toxicity test. OECD Guideline for testing of chemicals, 203, 1999, 9 p.

ISO 7346/2 Water quality-Determination of the acute lethal toxicity of substances to a freshwater fish [Brachydanio rerio Hamilton-Buchanan (Teleostei, Cyprinidae)] - Part 2: Semi-static method, 1984, 9 p. 